\title{
El modelo de Cheap Talk:
} su aporte a la divulgación de la información social y ambiental ${ }^{1}$

\author{
Cheap Talk Model: its contribution to the disclosure of social \\ and environmental information \\ O modelo de Cheap Talk: sua contribuição à divulgação \\ da informação social e ambiental \\ Carmen Stella Verón \\ Facultad de Ciencias Económicas \\ y Estadística, Universidad Nacional \\ de Rosario, Argentina. \\ E-mail:cveron@fcecon.unr.edu.ar \\ Sandra Patricia Pastor \\ Facultad de Ciencias Económicas, \\ Universidad del Centro de la Provincia \\ de Buenos Aires, Argentina. \\ E-mail:pastor@econ.unicen.edu.ar
}

Fecha de recepción: 30/10/2017 Fecha de aceptación: 17/12/2017

Palabras clave

- Divulgación

- Información social y ambiental

- Cheap talk

\section{Resumen}

La relación que las empresas construyen con sus grupos de interés queda determinada por sus revelaciones sociales, ambientales y económicas, ya sean voluntarias o de cumplimiento obligatorio y de acuerdo con Gray et ál. (1995) se puede analizar desde tres perspectivas teóricas: la de la decisión-utilidad, la teoría económica y la teoría sociopolítica. Estos enfoques teóricos coinciden en la importancia de la estrategia de divulgación.

Con un enfoque diferente, el modelo conocido como cheap talk, busca determinar el efecto de la información no vinculante en el comportamiento de las partes vinculadas a una negociación. El cheap talk hace referencia a una serie de mensajes sin costo, no vinculantes, y no verificables que sin embargo pueden afectar las creencias del oyente e incidir en sus decisiones. El cuestionamiento sobre la credibilidad de la información contenida en los reportes de responsabilidad social empresaria es un prejuicio que socava su importancia y claramente afecta su desarrollo, a pesar de los instrumentos de verificación y aseguramiento que la profesión contable ha diseñado para contrarrestarla. 
El objetivo de este trabajo es analizar e identificar el aporte del modelo de cheap talk en la divulgación voluntaria de información social y ambiental por parte de las empresas.

Los aportes de este modelo permiten considerar que la revelación de este tipo de información no sólo persigue mejorar la imagen corporativa, sino que puede ser una herramienta de transparencia y equidad informativa entre los diversos grupos vinculados.

\begin{abstract}
The relationship that companies build with their interest groups is determined by their social, environmental and economic disclosures. According to Gray et ál. (1995), these can be analyzed from three theoretical perspectives: the decision-utility perspective, the economic theory and the sociopolitical theory. These theoretical approaches agree on the importance of the dissemination strategy.

With a different approach, the cheap talk model seeks to determine the effect of non-binding information on the behavior of parties involved in a negotiation. Cheap talk refers to a series of messages that are free, non-binding and non-verifiable, but which can affect the listener's beliefs and exert some influence on their decisions. Doubts about the credibility of corporate social responsibility reports undermine their importance and affect their development, in spite of the instruments designed by the accounting profession to counteract them.

The objective of this work is to analyze and identify the contribution of the cheap talk model to the voluntary disclosure of social and environmental information by companies. The contributions of this model allow us to consider that the disclosure of this type of information not only seeks to improve the corporate image, but it can also be a tool to achieve transparency and fairness among the various groups involved.
\end{abstract}

Keywords

- Disclosure

- Social and environmental information

- Cheap talk

\title{
Resumo
}

0 relacionamento que as empresas constroem com seus grupos de interesse é determinado pelas suas revelações sociais, ambientais e econômicas, sejam elas voluntárias ou obrigatórias e que, de acordo com Gray et ál. (1995) pode se analisar desde três perspectivas teóricas: da decisão-utilidade, da teoria econômica e da teoria sociopolítica. Estas abordagens teóricas concordam com a importância da estratégia de divulgação.

Com uma abordagem diferente, o modelo conhecido como cheap talk, procura determinar 0 efeito da informação não vinculadora no comportamento das partes envolvidas em uma negociação. 0 Cheap Talk refere-se a uma série de mensagens sem custo, não vinculadoras e não verificáveis, que no entanto, podem afetar as crenças do ouvinte e influenciar suas decisões. 0 questionamento sobre a credibilidade da informação contida 
nos relatórios de responsabilidade social empresarial é um preconceito que prejudica sua importância e afeta de maneira clara seu desenvolvimento, apesar dos instrumentos de verificação e garantia que a profissão contábil tem projetado para neutralizá-la.

0 objetivo de nosso trabalho é analisar e identificar a contribuição do modelo de cheap talk na divulgação voluntária de informação social e ambiental por parte das empresas.

As contribuições deste modelo permitem considerar que a divulgação

Palavras-chave - Divulgação

- Informação social e ambiental

- Cheap talk deste tipo de informação não só procura melhorar a imagem corporativa, mas também pode ser uma ferramenta de transparência e equidade informativa entre os diversos grupos vinculados. 